\title{
HUBUNGAN ANTARA KEPERCAYAAN DIRI DENGAN KECEMASAN BERTANDING ATLET PENCAK SILAT DALAM MENGHADAPI SALATIGA CUP 2018
}

\author{
Jessi Triana ${ }^{1}$ Sapto Irawan ${ }^{2}$ Yustinus Windrawanto ${ }^{3}$ \\ Email:132015039@student.uksw.edu11, sapto.irawan@uksw.edu2 \\ yustinus.windrawanto@uksw.edu \\ Program Studi Bimbingan dan Konseling FKIP - Universitas Kristen Satya Wacana \\ Salatiga
}

\begin{abstract}
ABSTRAK
Penelitian ini bertujuan untuk mengetahui signifikansi hubungan antara kepercayaan diri dengan kecemasan bertanding atlet pencak silat dalam menghadapi Salatiga Cup 2018. Sampel total berjumlah 112 atlet. Penelitian ini dalam pengukuran data untuk variabel Nilai Pendidikan Karakter menggunakan skala sikap yang dikembangkan sendiri oleh peneliti dengan Kepercayaan Diri mengadopsi pada teori Dyah Ardhini (2012), dan variabel Kecemasan Bertanding mengadopsi pada teori Didera Sukmasari (2017).Teknik analisis data menggunakan Kendall's tau $b$. Berdasarkan dari hasil analisis data diperoleh hasil koefesien korelasi $\left(r_{x y}\right)$ sebesar $-0,732$ dan $p=0,000(<0,01)$. Artinya, bila skor variabel kepercayaan diri meningkat maka skor variabel kecemasan bertanding akan menurun, namun sebalinya apabila skor kepercayaan diri menurun, maka skor kecemasan bertanding akan meningkat. Yang dapat disimpulkan bahwa ada hubungan negatif yang signifikan antara kepercayaan diri dengan kecemasan bertanding atlet pencak silat dalam menghadapi Salatiga Cup 2018.
\end{abstract}

Kata Kunci: Kepercayaan Diri, Kecemasan Bertanding

PENDAHULUAN

Salah satu unsur yang berpengaruh dalam kehidupan manusia yaitu olahraga, karena dengan olahraga badan menjadi fit, sehat, dan dapat menjalani hari-hari dengan penuh semangat, selain itu dengan mengikuti dan menekuni olahraga kita dapat mengharumkan nama bangsa baik melalui kompetisi ditingkat daerah, nasional, maupun internasional. Salah satu olahraga yang banyak digemari oleh remaja adalah pencak silat. Pencak silat merupakan sistem bela diri yang diwariskan oleh nenek moyang sebagai budaya bangsa Indonesia sehingga perlu dilestarikan, dibina, dan dikembangkan (Kriswanto, 2015: 1).

Indonesia merupakan negara yang menjadi pusat ilmu beladiri tradisional pencak silat. Prinsip dasar olahraga pencak silat adalah pembelaan diri dan didalamnya terdapat nilai menyerang dan bertahan. Menyerang dan bertahan menjadi sebuah hal yang harus dimiliki oleh atlet pencak silat, ini yang akan menentukan kualitas seorang atlet pencak silat. Bertahan seperti mengelak, menghindari lawan untuk mengantisipasi serangan lawan, menjadi kunci pokok dalam konsep pertandingan pencak silat.

Prestasi atlet dipengaruhi oleh kepribadian atlet itu sendiri. Kepercayaan diri atau keyakinan diri diartikan sebagai suatu kepercayaan terhadap diri sendiri yang dimiliki setiap individu dalam kehidupannya, serta bagaimana individu tersebut memandang dirinya secara utuh dengan mengacu pada konsep diri 
(Rakhmat, 2000:53). Kepercayaan diri akan memperkuat motivasi atlet untuk mencapai keberhasilan dalam mengembangkan kemampuannya di pencak silat, selain itu apabila seorang atlet memiliki rasa percaya diri yang tinggi maka atlet tersebut dapat mengelola rasa cemas yang dimiliki. Karena semakin tinggi kepercayaan terhadap kemampuan diri sendiri, maka semakin kuat pula semangat dan motivasi untuk berprestasi (Feizi, M. R, 2014).

Beberapa atlet pencak silat yang sudah diwawancarai oleh peneliti pada saat observasi awal (Minggu, 1 Juli 2018) mendapatkan informasi bahwa atlet mengalami kecemasan saat akan menghadapi pertandingan, rasa cemas tersebut membuat atlet merasa tidak percaya diri terhadap kemampuan yang telah dimiliki dan dilatih selama ini. Kecemasan yang muncul membuat atlet tersebut tidak maksimal dalam menunjukkan dan mengeluarkan kemampuan yang dimiliki dipencak silat, sehingga kepercayaan diri atlet tersebut kurang dibandingkan dengan atlet pencak silat yang lain. Hal ini dapat mempengaruhi prestasi atlet tersebut pada saat mengikuti pertandinganpertandingan pencak silat berikutnya.

Untuk mempersiapkan pertandingan, para atlet harus berusaha dengan keras agar memenangkan pertandingan tersebut.Usaha para atlet tersebut diantaranya latihan setiap hari dan menjaga kesehatan tubuh. Selain usaha yang keras untuk mencapai prestasi atlet memerlukan rasa percaya diri, karena tanpa rasa percaya diri atlet tidak akan dapat mencapai prestasi yang diimpikan dan diinginkan. Menurut Komarudin (2013) atlet dengan kepercayaan diri kurang akan meragukan kemampuan yang dimilikinya. Atlet menjadi tegang dan putus asa. Keadaan ini akan merugikan atlet untuk menanmpilkan penampilan terbaiknya. Kurang percaya diri membuat atlet cemas ketika bertanding karena perasaan tegang yang dialaminya.Dalam dunia olahraga atlet sering kali dihadapkan pada situasisituasi yang penuh ketegangan. Situasi yang penuh ketegangan akan membuat atlet menjadi cemas. Kecemasan atlet ketika menghadapi perlombaan masih sangat tinggi, sehingga masih ada beberapa atlet yang menjadi kurang percaya diri.

Penelitian terdahulu yang dilakukan oleh Dhiki Triyono yang berjudul Hubungan Tingkat Kepercayaan Diri Dengan Kecemasan Atlet Pencak Silat (IPSI) Kota Bandung Sebelum Menghadapi Pertandingan POPDA/X Jawa Barat Tahun 2014 menunjukkan 
adanya hubungan negatif yang signifikan antara kepercayaan diri dengan kecemasan atlet pencak silat (IPSI) Kota Bandung sebelum menghadapi pertandingan POPDA/X dengan hasil $\left(r_{x y}\right)$ sebesar $-0,690$ dengan $\mathrm{p}<0,00$.

Penelitian lain yang dilakukan oleh Ade Firnanda yang berjudul Hubungan Antara Kepercayaan Diri Dengan Kecemasan Bertanding Pada Atlet Pencak Silat Kota Bukit Tinggi (2013) menunjukkan ada hubungan negatif yang signifikan antara kepercayaan diri dengan kecemasan bertanding pada atlet pencak silat Kota Bukit Tinggi dengan hasil $r_{x y}$ sebesar $-0,814$ dengan $p<0,00$.

Penelitian lain yang dilakukan oleh Lina Putri Rachmawati yang berjudul Hubungan Antara Kepercayaan Diri Dengan Kecemasan Menghadapi Pertandingan Pada Atlit Karate Unit Kegiatan Mahasiswa Institut Karate-di Indonesia Universitas Sebelas Maret (2013) menunjukan adanya hubungan positif antara kepercayaan diri dengan kecemasan menghadapi pertandingan pada Atlet Karate UKM INKAI UNS. Semakin tinggi kepercayaan diri, maka akan semakin tinggi kecemasan bertanding pada atlet karate, begitu juga sebaliknya semakin rendah kepercayaan diri, maka akan semakin tinggi kecemasan bertanding pada atlet karate.
Hasil analisis teknik korelasi product moment Pearson diperoleh nilai koefesien korelasi (R) sebesar -0,528; p =0,00 $(p<0,01)$. Terdapat hubungan negative antara kepercayaan diri dengan kecemasan menghadapi pertandingan saat menghadapi karate UKM INKAI INS. Dengan hasil tersebut, maka hipotesis penelitian diterima dan menunjukan bahwa kepercayaan diri dapat menjadi penentu timbulnya kecemasan menghadapi pertandingan. Kontribusi kepercayaan diri terhadap kecemasan menghadapi pertandingan adalah sebesar $27,9 \%$ yang ditunjukan oleh nilai $\mathrm{R}$ square sebesar 0,279.

Dari pemaparan latar belakang di atas menunjukkan adanya permasalahan tentang kecemasan yang berkaitan dengan kepercayaan diri. Berdasarkan permasalahan dan dua penelitian yang berkaitan tersebut, peneliti tertarik untuk melakukan penelitian tentang ada tidaknya hubungan kepercayaan diri dengan kecemasan bertanding atlet pencak silat dalam Salatiga Cup 2018.

\section{KAJIAN PUSTAKA}

\section{Kecemasan Bertanding}

Kecemasan bertanding adalah kondisi takut secara tidak rasional, berpikir yang tidak ada hubungannya merupakan gejala kecemasan. Kondisi somatic seperti jantung berdebar-debar, 
tangan berkeringat, dan sering buang air kecil, hal ini merupakan gejala dari gangguan kecemasan yang dialami oleh atlet yang akan bertanding. Pengertian secara umum menurut Komarudin (2013), kecemasan adalah manifestasi dari berbagai proses emosi yang bercampur baur, yang terjadi ketika orang sedang mengalami tekanan perasaan (frustasi) dan pertentangan batin (konflik). Serupa menurut Putri (2007) bahwa kecemasan merupakan ekspresi emosi individu terhadap hal/keadaan yang dianggapnya mengancam diri namun hal tersebut bukanlah hal yang nyata terlihat dan emosi ini diikuti oleh reaksi fisiologis.

Kecemasan terdapat dua komponen menurut Ardani Tristiadi Ardi (2012), yaitu komponen psikologisnya: khawatir, gugup, tegang, cemas, rasa tidak aman, takut, lekas terkejut. Komponen somatiknya: keringat dingin pada telapak tangan, tekanan darah meninggi, dll. Keringat dingin pada telapak tangan dipengaruhi oleh komponen psikologis, jadi keringat dingin yang dialami oleh banyak atlet olahraga dipengaruhi oleh komponen psikologis.

Jadi dapat disimpulkan bahwa kecemasan bertanding merupakan reaksi emosi negatif atlet terhadap keadaan tegang dalam menilai situasi pertandingan, yang ditandai dengan perasaan khawatir, was-was, dan disertai peningkatan gugahan system tubuh, sehingga menyebabkan atlet merasa tidak berdaya dan mengalami kelelahan karena senantiasa berada dalam keadaan yang depresi dan menekan.

Menurut Freud (dalam Ardani, 2007) kecemasan ada tiga macam, yaitu:

1. Kecemasan realitas, yakni kecemasan yang didasarkan pada bahaya nyata datang dari dunia luar

2. Kecemasan neurotik, yaitu kecemasan muncul dari id kemudian diekspresikan tanpa control

3. Kecemasan moral, yaitu kecemasan muncul ketika seseorang tidak mengikuti standar-standar kesadaran.

Menurut Amir (2012) yang mencerminkan faktor-faktor gejala dan gangguan kecemasan bertanding adalah sebagai berikut :

1. Faktor motorik, gejala dan gangguan kecemasan olahraga tampak pada diri atlet melalui keadaan raut muka dan dahi berkerut, gemetar, kaki terasa berat, sering menggaruk-garuk kepala, otot-otot sakit, sering jalan mondar-mandir, badan lesu, tubuh terasa kaku, dan mengalami ketegangan otot.

2. Faktor afektif, gejala dan gangguan kecemasan olahraga tampak pada diri 
atlet melalui pengakuan atlet seperti merasa cepat putus asa, sembrono, dan memiliki keraguan terhadap diri sendiri.

3. Faktor somatik, gejala dan gangguan kecemasan olahraga tampak pada diri atlet dalam keadaan jantung berdebar-debar keras, ingin buang air kecil, mengalami ketegangan, pernafasan tidak teratur, sering minum air, keringat dingin, dan susah tidur.

4. Faktor kognitif, gejala dan gangguan kecemasan olahraga tampak pada diri atlet dalam wujud tidak bisa berkonsentrasi, berpikir tentang halhal yang tidak berhubungan, dan pikiran negatif yang mengganggu konsentrasi.

\section{Kepercayaan Diri}

Menurut Miskell (dalam Rahayu, 2013) kepercayaan diri adalah penilaian yang relatif tentang diri sendiri, mengenai kemampuan bakat, kepemimpinan dan inisiatif, serta sifat-sifat lain dan kondisi yang mewarnai perasaan manusia (Rahayu, 2013). Liendenfield (2007) mendefinisikan kepercayaan diri adalah kepuasan seseorang akan diri sendiri. Liendenfield membagi dua jenis kepercayaan diri yaitu:

1. Kepercayaan diri batin adalah kepercayaan diri yang memberi kita perasaan dan anggapan bahwa kita dalam keadaan baik.

2. Kepercayaan diri lahir memungkinkan anak untuk tampil dan berperilaku dengan cara menunjukan kepada dunia luar bahwa ia yakin akan dirinya.

Berdasarkan pengertian-pengertian diatas tentang kepercayaan diri dapat disimpulkan bahwa kepercayaan diri adalah aspek kepribadian pada diri seseorang yang menunjukan rasa kepuasan individu tersebut.

Faktor-faktor yang mempengaruhi kepercayaan diri (Rahayu , 2013) yaitu:

a. Orang tua

Orang tua merupakan faktor terpenting dalam membangun kepercayaan diri anak. Pendidikan keluarga merupakan pendidikan pertama dan utama yang sangat menentukan baik buruknya kepribadian anak.

b. Lingkungan

Pendidikan disekolah merupakan salah satu contoh lingkungan yang sangat berperan penting dalam menumbuh kembangkan kepercayaan diri anak. Lingkungan sekolah memegang peranan penting dalam kegiatan sosialisasi. Dengan demikian, kegiatan belajar dan 
bermain dapat meningkatkan kepercayaan diri anak.

c. Guru (pelatih)

Guru (pelatih) sebagai pendidik berperan dalam membentuk dan menumbuhkan kepercayaan diri anak, yaitu dengan memberikan sifat yang hangat dan ramah, karena juga berperan sebagai model bagi anak.

Lauster (1992) mengemukakan aspek-aspek kepercayaan diri dari yang positif, yaitu:

a. Keyakinan akan kemampuan diri, yaitu sikap positif individu tentang dirinya bahwa ia mengerti sungguhsungguh akan apa yang dilakukan.

b. Optimis, yaitu sikap positif individu yang selalu berpandangan baik dalam menghadapi segala hal tentang diri, harapan, dan kemampuan.

c. Objektif, yaitu sikap individu yang memandang permasalahan ataupun segala sesuatu sesuai dengan kebenaran pribadi atau menurut dirinya sendiri.

d. Bertanggung jawab, yaitu kesedihan individu untuk menanggung segala sesuatu yang telah menjadi konsekuensinya.

e. Rasional dan realistis, yaitu kemampuan menganalisis suatu masalah, sesuatu hal, sesuatu kejadian dengan menggunakan pemikiran yang dapat diterima oleh akal dan sesuai dengan kenyataan.

\section{METODE PENELITIAN}

Penelitian ini menggunakan jenis penelitian kuantitatif. Populasi dalam penelitian ini adalah atlet pencak silat yang mengikuti pertandingan Salatiga Cup 2018 yang berjumlah 112 atlet. Sampel yang digunakan dalam penelitian ini adalah dengan menggunakan random sampling dengan tingkat kesalahan 5\%.

Dalam penelitian ini terdapat 2 variabel yaitu variabel bebas (X) dan variabel terikat (Y). Variabel independen (bebas) dalam penelitian ini yaitu Kepercayaan Diri (X) dan Variabel dependen (terikat) dalam penelitian ini yaitu Kecemasan Bertanding (Y).

Hasil uji validitas diperoleh hasil bahwa kepercayaan diri (X) yang valid ada 45 item. Item-item pernyataan tersebut mempunyai koefisien corrected item to total correlation yang terendah sebesar 0,372 - 0,841 dengan reliabilitas sebesar 0,976 yang berkategori sangat bagus. Kecemasan Bertanding (Y) yang valid ada 40 item. Item-item pernyataan tersebut mempunyai koefisien corrected item to total correlation yang terendah sebesar 0,368 - 0,841 dengan reliabilitas sebesar 0,972 yang berkategori sangat tinggi. 


\section{HASIL DAN PEMBAHASAN}

\section{Analisis Deskripsi Kecemasan \\ Bertanding}

Berdasarkan distribusi frekuensi frekuensi dapat diketahui bahwa kecemasan bertanding atlet pencak silat yang menghadapi Salatiga Cup 2018 sebagian besar berada dalam kategori sedang dengan persentase sebesar $66,2 \%$.

\section{Analisis Deskripsi Kepercayaan Diri}

Berdasarkan distribusi frekuensi frekuensi dapat diketahui bahwa kepercayaan diri atlet pencak silat yang menghadapi Salatiga Cup 2018 sebagian besar berada dalam kategori sedang dengan persentase sebesar $56,25 \%$.

\section{Uji Hipotesis}

Uji hipotesis bertujuan untuk mengetahui ada atau tidak ada hubungan (korelasi) antara kecemasan bertanding dengan kepercayaan diriatlet pencak silat yang mengikuti Salatiga Cup tahun2018. Pengujian korelasi menggunakan kendall's tau dengan menggunakan SPSS 20.0 for Windows, hasil uji korelasi dapat dilihat pada tabel 1 sebagai berikut :

\section{Tabel 1. Analisis Korelasi}

\section{Correlations}

\begin{tabular}{|r|r|l|}
\hline & $\begin{array}{r}\text { Kepercay } \\
\text { aanDiri }\end{array}$ & $\begin{array}{l}\text { Kecemasa } \\
\text { Bertanding }\end{array}$ \\
\hline $\begin{array}{l}\text { Keper Correlation } \\
\text { cayaa Coefficient }\end{array}$ & 1.000 & $-.732^{* *}$ \\
\hline
\end{tabular}

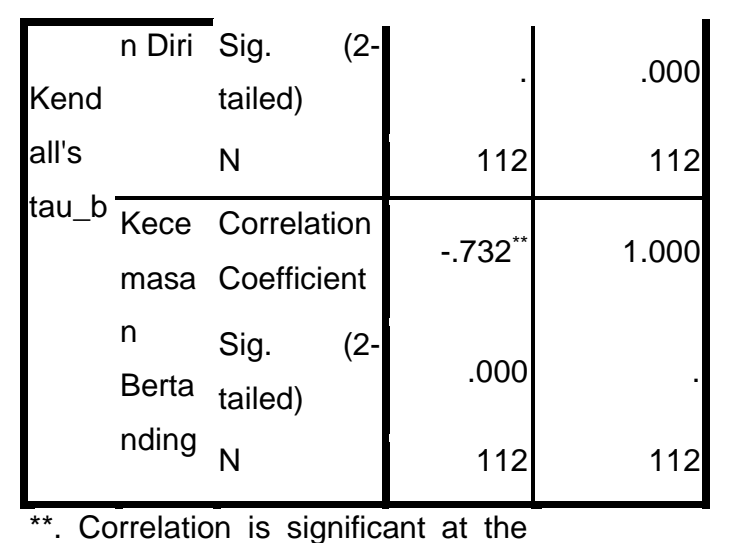

0.05 level (2-tailed).

Berdasarkan uji hipotesis yang telah dilakukan, menunjukkan hasil bahwa terdapat hubungan yang signifikan antara kepercayaan diri dengan kecemasan saat bertanding pada atlet pencak silat yang mengikuti Salatiga Cup tahun 2018. Diketahui koefisien korelasi antara kepercayaan diri dengan kecemasan bertanding sebesar -,732 dengan demikian hipotesis alternatif diterima dan berbunyi terdapat hubungan negatif yang signifikan antara kepercayaan diri dengan kecemasan bertanding atlet pencak silat yang mengikuti Salatiga Cup tahun 2018.

Hasil penelitian ini mendukung penelitian yang dilakukan oleh Dhiki Triyono (2007) yang berjudul Hubungan Tingkat Kepercayaan Diri Dengan Kecemasan Atlet Pencak Silat (IPSI) Kota Bandung Sebelum Menghadapi Pertandingan POPDA/X Jawa Barat Tahun 2014 menunjukkan adanya hubungan negatif yang signifikan antara kepercayaan diri dengan kecemasan atlet 
pencak silat (IPSI) Kota Bandung sebelum menghadapi pertandingan POPDA/X dengan hasil $\left(\mathrm{r}_{\mathrm{xy}}\right)$ sebesar 0,690 dengan $p<0,00$.

Hasil penelitian ini juga mendukung pernyataan Viderman (2007), menunjukkan bahwa kepercayaan diri memegang peranan penting dalam menurunkan kecemasan yang dialami oleh setiap partisipan. Dari hasil analisis data, bahwa kepercayaan diri dan kecemasan mempunyai korelasi pada partisipan. Apabila kecemasan partisipan tinggi, maka kepercayaan diri partisipan rendah.

Sejalan dengan pendapat Fitri Yulianto, H. Fuad Nashori (2006) bahwa kurang percaya diri akan kemampuannya pada saat bertanding, akan membuat atlet akan mengalami ketegangan sebelum bertanding. Ketegangan merupakan bagian dari gangguan kecemasan. Penelitian yang dilakukan oleh Woodman dan Hardy (2003) dalam sebuah meta analisis telah mengungkapkan bahwa adanya hubungan antara kepercayaan diri dengan kecemasan bertanding.

Berdasarkan uraian diatas dapat dijelaskan bahwa dengan adanya kepercayaan diri akan membantu atlet dalam mengendalikan dan melakukan penyesuaian dengan takanan-tekanan yang ada dalam pertandingan.
Pengendalian dan penyesuaian yang baik dapat menurunkan tingkat kecemasannya dalam menghadapi pertandingan. Oleh karena itu, apabila atlet memiliki kepercayaan diri yang baik, maka tingkat kecemasan bertandingnya akan rendah.

Kepercayaan diri yang baik ditunjukkan dengan adanya sikap positif yang didasari keyakinan dan kemampuan. Sikap positif yang didasari keyakinan dan kemampuan mengenai ketakutan dan tekanan-tekanan pertandingan membantu atlet dalam menyalurkan tekanan-tekanan tersebut. Tersalurkannya tekanan-tekanan tersebut akan menimbulkan sikap perasaan tenang dan lebih rileks saat akan mengahadapi pertandingan yang akhirnya dapat mereduksi kecemasannya dalam menghadapi pertandingan.

Selain itu, kepercayaan diri merupakan salah satu aspek dari kepribadian yang dimiliki oleh setiap atlet untuk mengatasi kecemasan pada saat akan bertanding. Orang yang memiliki rasa percaya diri yang rendah akan bertindak lebih ragu atau hati-hati, karena tidak percaya pada kemampuan yang mereka miliki meragukan diri mereka sendiri (Susilowati, 2013).

\section{PENUTUP}

Berdasarkan dari penelitian yang sudah dilakukan ini, maka dapat ditarik kesimpulan bahwa, ada hubungan negatif 
yang signifikan antara kepercayaan diri dengan kecemasan bertanding dengan koefesien korelasi $\left(\mathrm{r}_{\mathrm{xy}}\right)$ sebesar $-0,732$ dan $\mathrm{p}=0,000(<0,01)$. Artinya, bila skor variabel kepercayaan diri meningkat maka skor variabel kecemasan bertanding akan menurun, namun sebalinya apabila skor kepercayaan diri menurun, maka skor kecemasan bertanding akan meningkat.

\section{Saran}

$$
\text { Pelatih diharapkan dapat }
$$

meningkatkan rasa percaya diri atlet, dengan cara memberikan dukunganberperan dalam membentuk dan menumbuhkan kepercayaan diri anak, yaitu dengan memberikan sifat yang hangat dan ramah, karena juga berperan sebagai model bagi anak dan memberikan motivasi kepada atlet bahwa atlet mampu menunjukkan atau menampilakan yang terbaik saat pertandingan berlangsung. Pelatih mendukung penuh saat atlet sedang bertanding, sehingga atlet merasa diberi dukungan dan termotivasi untuk menjadi juara.

Para atlet diharapkan mampu untuk meningkatkan rasa percaya diri dengan cara lingkungan disekolah karena sekolah memegang peranan penting dalam kegiatan sosialisasi. Dengan demikian, kegiatan belajar dan bermain dapat meningkatkan kepercayaan diri anak, sehingga peran itu akandimiliki saat akan menghadapi pertandingan sehingga atlet merasa yakin dengan kemampuan yang dimiliki dan meminimalisasi rasa cemas yang adapada dirinya.

\section{DAFTAR PUSTAKA}

Ade. Firnanda. 2013. Hubungan Antara Kepercayaan Diri Dengan Kecemasan Bertanding Pada Atlet Taekwondo Kota Bukit tinggi. Jurnal Psikologi Volume 2 Nomor 2.

Amir, 2012. Faktor-faktor Gejala dan Gangguan Kecemasan Bertanding.

Ardani,Tristiardi A., Yulia., Rahayu, Iin Tri. Psikologi Klinis. Yogyakarta: Graha Ilmu.

Dhiki, Triyono. 2014. Hubungan Tingkat Kepercayaan Diri Dengan Kecemasan Atlet Pencak Silat (IPSI) Kota Bandung. Skripsi. Universitas Negeri Bandung.

Didera, Sukmasari. 2017. Hubungan Antara Kepercayaan Diri Dengan Kecemasan Bertanding Pada Atlet Pencak Silat Kota Bukit Tinggi. Skripsi. FKIP: Universitas Negeri Medan. (diunduh tanggal 6 April 2019 Pukul 06.15 WIB).

Dyah. 2012. Hubungan Motivasi Berprestasi Dan Kepercayaan Diri Dengan Prestasi Belajar Siswa Kelas Olahraga SMP Negri 4 Purbalingga. Skripsi. Universitas Negeri Yogyakarta. (diunduh tanggal 1 April 2019 Pukul 11.15 WIB).

Fitri, Yulianto., H, Fuad Nashori. 2006 Hubungan Dukungan Sosial Dengan Kepercayaan Diri Pada Atlet Cabang Olah Raga. Skripsi. Universitas Negeri Surabaya. 
(diunduh tanggal 2 April 2019 Pukul 14.15 WIB).

Feizi, M. R. 2014. Anak Usia TK Menumbuhkan Kepercayaan. Jakarta: BumiAksara.

Komarudin. 2013. Psikologi Olahraga. Bandung: PT. Remaja Rosdakarya.

Kriswanto. 2015. Pencak Silat. Yogjakarta: PT. Pustaka Baru.

Lina, Putri Rachmawati. 2013. Hubungan Antara Kepercayaan Diri Dengan Kecemasan Menghadapi Pertandingan Pada Atlit Karate Unit Kegiatan Mahasiswa Institut Karate-di Indonesia. Jurnal Bimbingan dan Konseling. Universitas Sebelas Maret. Vol. 1 No. 2.

Lauster. 1992. Tes Kepribadian (Terjemahan D.H. Gulo). Jakarta: Gramedia Bumi Aksara

Putri. 2007. Hubungan Antara Intimasi Pelatih - Atlet Dengan Kecemasan Bertanding Pada Atlet Ikatan Pencak Silat Indonesia (Ipsi) Semarang. Skripsi: FKIP. UNNES. Volume 2. Nomor. 2. (diunduh tanggal 4 April 2019 Pukul 21.15 WIB).

Rahayu, Almira. 2012. Hubungan Kepercayaan Diri dengan Kecemasan Bertanding Pemain Karate di Institut Karate Do Indonesia di Bogor. Skripsi. Universitas Indraprasta PGRI. Vol. 10. No. 1.(diunduh tanggal 22 April 2019 Pukul 16.15 WIB).

Rakhmat. 2000. Metode Penelitian Komunikasi. Bandung: PT. Remaja Rosdakarya.

Susilowati, Setya. 2011. Hubungan Kepercayaan Diri dengan Kecemasan Bertanding Pemain Bulutangkis di PB Djarum Kudus.
Jurnal Bimbingan Konseli Islam.STAIN Kudus. Vol. 2. No. 2. (diunduh tanggal 23 April 2019 Pukul 08.45 WIB).

Viderman. 2007. Metode Penelitian. Bandung: CV. Alfabeta.

Woodman dan Hardy. 2003. TheImpact of Pre-Competition Angeron SelfConfidence and Success of Volleyball Players in Premier League and its Relation with Athletes' Experience) Journal of Educational and Management Studies Volume.41 Nomor.15 November 2014. (diunduh tanggal 2 April 2019 Pukul 17.15 $W I B)$. 